Editorial

\title{
Preface for Symposium on Globalization and the Brain Drain in the Journal of Development Economics, 2010
}

The papers in this special issue were all presented at a conference on "Globalization and the Brain Drain: Theory, Evidence and Policy", organized at Bar-Ilan University and the Hebrew University on December 9-11, 2008, in Ramat Gan and Jerusalem, Israel, with the support of the Adar Foundation, the Schnitzer Foundation for Research on the Israeli Economy and Society, and the Ben-Porath Fund, Maurice Falk Institute for Economic Research in Israel. Eric Gould and Hillel Rapoport served as organizers.

The symposium on "Globalization and the Brain Drain" in this journal, edited by Gordon Hanson and Hillel Rapoport, follows by 35 years a symposium that I edited on practically the same subject in this very journal in 1975 (Vol. 2. No. 3).

The earlier symposium contained analytical and econometric studies which were partly, though by no means entirely, motivated by the proposal I had advanced at the time to "tax the brain drain." This proposal, now known as the Bhagwati Tax (rather like the Tobin Tax on capital flows), was prompted by the analysis of skilled migration in the framework of the "diaspora" that was evolving.

The subject matter of the "brain drain," while it has witnessed renewed interest in the analysis of the Bhagwati Tax as evidenced by the latest analyses by John Wilson in this symposium and elsewhere, ${ }^{2}$ has also developed in many new directions, prompted by the vastly greater globalization on the dimension of flows of humanity across borders. The increased globalization has meant that many more professional migrants now work other than in their own countries of origin. Besides, many more now go back and forth so that issues such as return and to-and-fro migration must now be analyzed, rather than once-and-forever shift of migrants in the models we generally used in the 1960s and 1970s. Globalization has also meant that the ramifications of the diaspora "model" have now become important. Thus, for instance, we now must ask more pointedly what institutional support structures would maximize the contribution that the skilled migrants settled elsewhere can make to their countries of origin and (often) continuing nationality.

It is nonetheless instructive to begin by recalling how migration was treated in policy analyses in the early postwar years and what we learnt from them that endures as critical elements of modern analysis of the phenomenon.

\footnotetext{
${ }^{1}$ See, in particular, the econometric studies in chapters 3 and 4 by George Psacharopoulos and Robert E.B. Lucas respectively in volume II of Brain Drain and Taxation, Bhagwati (1976).

${ }^{2}$ See in particular his contribution, and that of John McHale, in Bhagwati and Hanson (2009). Also, there is an earlier volume of essays by MIT Press on the subject, edited by Bhagwati and Wilson (1989).
}

The early discussions and analytical models that were built to inform them, distinguished between both unskilled and skilled (professional) migration flows. They also distinguished between ${ }^{3}$ the welfare implications for the "sending" (or "home") countries and the "receiving" (or "host") countries. While there were indeed flows of the unskilled from poor to poor countries, as when migrants from Malawi and Botswana went to South Africa to work in the mines, the typical analysis centered on unskilled migrants from the poor to the rich countries, as with the guestworkers (the gastarbeiters) who went from Turkey and Yugoslavia to European countries, such as West Germany. Similarly, while the phrase "brain drain" had originated in the context of the European outflow of scientists to the United States, it quickly shifted to the phenomenon of outmigration from poor countries like India to rich countries like the United States.

For unskilled migration, which was legally managed, the presumption was that it was a win-win phenomenon for both the sending and the receiving countries. A Turkish guestworker would find employment at improved income in Germany, simultaneously relieving Turkey's unemployment and underemployment, while providing the labour that permitted a German growth revival that would otherwise be handicapped by the massively depleted labour supply as a result of the Second World War.

But when it came to skilled migration, the phenomenon was viewed very differently, as a "lose" proposition by the poor sending countries which saw it as a "brain drain" that would handicap their development, whereas the receiving rich countries saw it as a "win" proposition whereby they augmented their skilled labour supply. ${ }^{4}$

Scientific analysis of skilled migration at the time, beginning with the writings of Harry Johnson $(1965,1967)$ and Johnson (1967), Grubel and Scott (1966) and resulting in a substantial literature reviewed in the earlier JDE Symposium by Bhagwati and Rodriguez (1976), made some important analytical points that are worth recalling.

\footnotetext{
${ }^{3}$ This argument applied equally to the influx of workers from population-andpoverty-intensive Bangladesh, Pakistan and India into the Middle East with sparse populations and oil-bonanza induced growth requiring an influx of unskilled (and even skilled) labour supply. The economist Michael Piore (1979) has argued, in his celebrated book, Birds of Passage, that the United States did not need this labour influx until much later because the growth of manufacturing production in the North was supported by the influx of black labour from the South.

4 The concern over "brain drain," as it happens, arose first between the rich countries: European countries were worried about the loss of their professional manpower to the United States. Quickly, however, the issue was transposed to the outflow of professionals from the poor to the rich countries, where it has since then been located.
} 
First, it became clear that there was no analytical symmetry between capital flows and migration. When a nation exports capital, the group over which one defines welfare is unchanged. But when outmigration occurs, the group over which welfare is defined can change. Thus, the welfare function for a c country will depend on the sociological and political nature of the migration. Therefore, it is necessary to disaggregate the welfare impacts on those left behind in the home country, the migrants themselves, and the host country nationals who receive the immigrants. "National welfare" will depend on which country the migrants are counted in. Thus, an Indian migrant doctor in the United States may be counted as part of Indian welfare or American welfare or neither or both.

Second, once we disaggregate the phenomenon, then it also follows that the three groups do not experience welfare impacts in the same direction. Since we are discussing migration within the framework of immigration restrictions which segment the receiving and the sending countries - illegal migration dilutes this segmentation but does not eliminate it - evidently we can assert that migration will increase overall (world) welfare. Then again, for voluntary migration, we can presume that the migrants improve their welfare. But those left behind may lose (as the losers probably have little voice in policymaking) and host country nationals will gain (the presumptions being that else the immigration would not be allowed, with illegal migration of the skilled being rare).

Third, the presumption that many had of the effect on those left behind was indeed a pessimistic one when the early analytical literature began in the 1970s. Many in the poor countries, with small stocks and new additions of skilled professionals, worked with the view that if one professional went away, the productivity of the rest would collapse: one Bhagwati going away to MIT would mean that the rest of the small economists' group at Delhi School of Economics would get a big hit and also that it may mean that all others would out-migrate also to Yale, Princeton and Columbia, decimating the Delhi School. This "essential factor" view is a great exaggeration, of course.

Then again, many thought that there are substantial externalities if certain professionals, such as doctors, depart. The sheer availability of doctors brings utility from potential patients in excess of what the doctor earns from his patients. But then, one may counter that this argument applies to rural areas where doctors are scarce, whereas the doctors actually are cheek by jowl in the cities. But then, the worry about migration of doctors in the static context of a given supply can be partly restored along the lines of Bhagwati and Hamada (1976) who argued that as doctors get too abundant in the cities, their earnings drop, prompting them to actually move into towns and the into villages (if only on a 1 day a week basis).

Fourth, the early literature than asked: if those left behind lose, could not the gains of the migrants from being allowed to enter the rich country economies, with higher incomes than they earned in their home c countries, be taxed to compensate the losers? This is one notion that led to the idea of taxing the brain drain.

An added argument for such taxation was that the gains to the migrants represented "rents" and therefore they were a perfect target for raising resources for development in the home countries regardless of whether those left behind had lost from the emigration or not.

One may well ask, as I did, whether the phenomenon of outmigration of professionals could be exploited by the home country, even when those left behind gained, to add to those gains. This led immediately to the notion of the diaspora and use of it to maximize the payoffs to a country from its outflow of skilled professionals. In this context, the tax on the brain drain represented a way in which those left behind could share in the gains accruing to the emigrants from their leaving to work in the rich countries.

All these arguments were compatible with the view that the rich receiving countries would gain from the influx of skilled manpower: the tax would take moneys from the rents earned by the migrants, not from the host country nationals whose welfare gains would not be directly affected by the tax. In fact, the legal immigration systems in many rich countries have been shifted, in different ways, to admit more skilled. At the same time, the legal immigration of the unskilled has come to be viewed in the rich countries as undesirable, with the unskilled immigration now mostly diverted to illegal channels. ${ }^{5}$ In fact, several economists such as Julian Simon and Gary Becker have been arguing for a substantial shift of legal immigration to skilled professionals, even suggesting that legal quotas be auctioned off to the highest bidders. ${ }^{6}$

This symposium takes major strides towards an updated, and indeed insightful, analysis of the ongoing "Brain Drain" phenomenon, using both theoretical and quantitative analyses. The phenomena of return migration and the diaspora, as also more conventional issues such as taxation of the brain drain and the determinants of skilled outmigration, are illuminated with great success.

John Wilson carries the analysis of the Bhagwati Tax probes yet further by analyzing the objection that the revenues may be spent by governments that waste them. Jeffrey Grogger and Gordon Hanson skillfully integrate the two phenomena that the more highly educated are more likely to emigrate and that they are also more likely to settle in the receiving countries. Bruce Weinberg produces a fascinating analysis that shows that democracy produces more accomplished skilled professionals but also leads to higher rates of out-migration: a contribution that has an important lesson also for the growing literature on democracies. Complementary analysis of the role of intellectual property rights in skill creation and competition for "brains" is the contribution of Peter Kuhn and Carol Ausland. Return migration is the subject of an interesting empirical investigation by John Gibson and David McKenzie and, among other issues, also of the analysis by Christian Dustmann, Yoram Weiss and Itzhak Fadlon. The effects of the diaspora are studied by Michael Beine, Frederic Docquier and Caglar Ozden who examine the effect of diasporas on migration flows. Hillel Raporport and Andrew Mountford build a dynamic model that analyzes the impact of skilled migration on the distribution of world income, with suggestive results; the paper should be read alongside the contribution by David Stadelman and Volker Grossman who use instead an overlapping-generations model to suggest that skilled outmigration could increase inequality between the sending and receiving countries.

So we witness in this symposium a remarkable deepening of our understanding of the phenomenon of skilled migration, and of the implications that follow for several areas of public policy.

\section{References}

Bhagwati, J. (Ed.), 1976. The brain drain and taxation volume II: theory and empirical analysis, Amsterdam: North Holland.

Bhagwati, J., 2000. "Why borjas fails to persuade", in The Wind of the Hundred Days: how Washington mismanaged globalization. MIT Press, Cambridge.

Bhagwati, J., 2010. "Ideas on immigration", author's letter to magazine. De Economist 396, 16.

Bhagwati, J., Hamada, K., 1976. The brain drain, international integration of markets for professionals and unemployment. In: Bhagwati, J. (Ed.), The brain drain and taxation volume II: Theory and empirical analysis, Amsterdam: North Holland.

Bhagwati, J., Hanson, G. (Eds.), 2009. Skilled Immigration Today: Prospects, Problems, and Policies. Oxford University Press, New York.

Bhagwati, J., Rodriguez, C., 1976. Welfare - theoretical analyses of the brain drain. In: Bhagwati, J. (Ed.), The brain drain and taxation volume II: theory and empirical analysis, Amsterdam: North Holland.

\footnotetext{
${ }^{5}$ This is about to change, in turn, as many European countries with rapidly reduced birth rates and even China as a result of the success of the one-child policy, face shortages of unskilled labour, much as postwar Europe did. Maybe we will see the return of guestworker programs on a massive scale, not just to siphon off the illegal influx but also quite simply to supply the unskilled labour for a growing economy as the demographics lead to reduced labour supply.

${ }^{6}$ I have argued against this proposal in several writings. See in particular Bhagwati (2000) and my response in a Letter to the Editor, Bhagwati (2010), to an "Economics Focus "article in The Economist on Becker's long-standing proposal which the illinformed writer wrongly assumed was a new proposal.
} 
Bhagwati, J., Wilson, J. (Eds.), 1989. Income taxation and international mobility. MIT Press. Grubel, H., Scott, A., 1966. The international flow of human capital. The American Economic Review 56, 268-274.

Johnson, H., 1965. The economics of the 'brain drain': The Canadian case. Minerva 3. 299-311.

Johnson, H., 1967. Some economic aspects of brain drain. Pakistan Development Review 3, 379-411.

Lucas, R., 1976. The supply-of-immigrants function and taxation of immigrants incomes: an econometric analysis. In: Bhagwati, J. (Ed.), The brain drain and taxation volume II: theory and empirical analysis, Amsterdam: North Holland.

Piore, M., 1979. Birds of passage. Cambridge University Press, New York.
Psacharopoulos, G., 1976. Estimating some key parameters in the brain drain taxation model. In: Bhagwati, J. (Ed.), The brain drain and taxation volume II: Theory and empirical analysis, Amsterdam: North Holland.

Jagdish Bhagwati

E-mail address: jb38@columbia.edu. 